\title{
Expertise and its Contribution to the Notion of Protective Factors in Offender Rehabilitation
} and Desistance

\author{
Dr Claire Nee and Dr Zarah Vernham
}

To appear in a special issue of Aggression \& Violent Behavior on Protective Factors

\begin{abstract}
In the field of offender corrections, a preoccupation with risk prediction has come at the expense of explanation, and an overemphasis on risk factors has come at the expense of understanding protective factors. Some strides have been made in describing and categorising the types of factors that protect young people from a life of crime, or promote competencies and potentials that help them avoid it altogether. We argue, however, that like the field of dynamic risk factors, we know very little about the nature and function of these features, beyond describing them. The article describes theory and research associated with expertise and its qualities and value as both a risk and a protective factor in the prevention of crime. It draws from literature in forensic psychology, criminology, resilience and neuroscience.
\end{abstract}

Key words: expertise; dysfunctional expertise; protective factors; risk; desistence

\section{Introduction}

Knowledge of the link between protective factors and offending is crucial to understanding why some individuals continue to offend whilst others desist from offending, or never begin despite considerable adversity and risk in their backgrounds. However, the notion of 'protection' has been hugely neglected within the domains of forensic and criminal psychology. Actuarial risk assessment, which is vital to criminal justice practice and offender management, and the prominence of the Risk-Need-Responsivity model of offender rehabilitation (Andrews, Bonta \& Wormith, 2006), has led academics and practitioners in these fields to focus on the risk that an individual poses to either themselves or other members of the public (Beech, Fisher, \& Thornton, 2003). When assessing risk, static risk factors (i.e. historical, unchangeable features, such as number of previous convictions or age of first conviction) and dynamic risk factors (i.e. changeable features, such as emotional dysregulation or poor coping skills) are measured to calculate the likelihood that an individual will reoffend (Bonta, 1996): The more risk factors that are present, the more likely the offender will offend again. Whilst focusing on risk is important for protecting the individuals themselves, the public and those working in legal and correctional facilities (Andrews \& Bonta, 2003), it does mean that those factors associated with protecting the individual from 
reoffending have been ignored despite having huge implications for offender intervention, management and treatment. Such factors are referred to as Protective Factors. Over recent years, academics and practitioners in the fields of forensic psychology and criminology have started to explore this notion of 'protection' by considering those factors that might reduce rather than increase the likelihood of an individual reoffending. An interesting topic of theory and research with a wealth of robust experimental research to support it, and which has interesting implications for both increasing 'protection' and risk is that of expertise. In this article, we will first discuss the nature of protective factors, arguing that they are qualities or traits that are inherently positive within the individual and are not just factors that mitigate risk. We will highlight that the issues associated with conceptualising protective factors are similar to those associated with conceptualising dynamic risk factors (see Vernham \& Nee, 2015 for a review). We will then turn to a consideration of expertise and its unique status as potentially both a risk and protective factor. Finally, the article will discuss the implications of expertise and protective factors for rehabilitation and desistance.

\section{What are protective factors?}

Identifying and addressing the predictors of offending is important for prevention and intervention, with risk factors traditionally being the focus. However, this risk-based approach to rehabilitation and treatment is very much deficit-focused; hence, there is an emphasis on the individual's problems and little consideration of the individual's strengths (Maruna \& LeBel, 2003; Willis \& Ward, 2013). The focus on deficits can have negative consequences for an offender and result in them being unmotivated to engage in treatment, leading to increased reoffending rates (Wilson \& Yates, 2009). As a result, many researchers (e.g. de Vogel, de Vries Robbé, de Ruiter, \& Bourman, 2011; de Vries Robbé, de Vogel, \& de Spa, 2011; Salekin \& Lochman, 2008; Thornton, 2013; Ttofi, Farrington, Piquero \& DeLisi, 2016; Ward \& Maruna, 2007) have urged criminal practitioners to re-align this risk-based approach and to consider balancing the assessment of risk with the assessment of an individual's strengths (i.e. criminal practitioners need to consider the individual's protective factors). The inclusion of protective factors in assessment and treatment is important because: (1) research shows that combining risk factors (deficits) and protective factors (strengths) improves the predictive validity of assessments compared to when risk factors alone are measured (de Vries Robbé, de Vogel, \& Douglas, 2013; Lodewijks, de Ruiter \& Doreleijers, 2010);

(2) a biased focus on risk can lead to over prediction of risk and poor risk management and treatment planning (Rogers, 2000); and (3) a focus on deficits can be stigmatising to individuals and lead to a negative relationship between the assessor and assessee (Attrill \& Liell, 2007). 
Although risk factors can predict crime, protective factors can promote desistance or the prevention of the criminal career beginning at all; thus, can also be predictive of recidivism (Thornton, 2013). The notion of protection developed from the concept of resilience. An individual can be deemed as resilient if they experience adverse events (e.g. child neglect or sexual abuse) but do not develop maladaptive coping strategies and behaviours (e.g. depression, anxiety, violent offending; Masten, 2001). This leads to the following question: 'Why is it that out of a group of individuals who experience similar adverse backgrounds only some develop a healthy level of functioning, whilst others develop a harmful level of functioning'? Resilience is believed to be fostered by protective factors (Mrazek \& Mrazek, 1987), individual characteristics which function to protect individuals from the negative outcomes typically associated with a dysfunctional background. However, instead of describing a list of protective factors thought to contribute to resilience (e.g. trustful and forgiving character, self-control, stable caregiving, supportive family, positive peer networks; Afifi \& MacMillan, 2011), we should instead be examining how and why such factors help only some individuals manage in the face of adversity.

The evidence regarding the impact of protective factors against crime is far less well established than the evidence for risk factors (Tolan, 2000). At present, there is no universal definition of 'protective factors' nor is there a consensus amongst researchers about how protective factors relate or interconnect with risk factors. Some researchers say protective factors are the absence (Costa, Jessor \& Turbin, 1999) or 'mirror image' of risk factors (White, Moffitt, \& Silva, 1989), whilst others state that protective factors are variables that interact with risk factors to nullify their effects (Rutter, 1985) or are variables that predict low probability of offending among a high risk group (Werner \& Smith, 1982).

In recent years, scholars have started to discuss what protective factors might entail in a more detailed way. In 2014, de Vries Robbé developed a model which attempted to explain four key mechanisms in which protective factors have an impact: (1) The risk reducing effect, which advocates that some protective factors reduce risk factors directly; (2) The moderator or buffering effect, which advocates that protective factors lessen the strength of the relationship between a risk factor and offending as opposed to changing the risk factor directly; (3) The main effect, which advocates that protective factors have a general positive effect (rather than influencing specific risk factors) and thus offer overall protection leading to a reduction in reoffending; and (4) The motivator effect, which advocates that protective factors have a positive influence on each other, so that specific protective factors enhance or facilitate the development of other protective factors. However, problems do arise from de Vries Robbé’s model of protection because, whilst it is beneficial in terms of risk-prediction, it fails to incorporate an explanatory component. It does not tell us about the nature of protective factors, only what they might do. The model does not explain 
why individuals continue to offend or desist from offending; hence, it has very little impact on offender intervention and treatment. This lack of explanation is also an issue with the current categorisation and definition of dynamic risk factors (Vernham \& Nee, 2015). At present, dynamic risk factors are merely a list of factors that increase risk, with no conceptualisation of the underlying casual mechanisms and how such factors increase the likelihood of reoffending. If we have no explanation of how and why risk factors increase risk of reoffending and we have no understanding of how and why protective factors decrease risk of reoffending, then all that remains are lists of factors that are indicators or predictors of recidivism. Furthermore, this current lack of explanation with regard to the underlying causal mechanisms of offending behaviours in terms of risk and protective factors means that developing an understanding of how protective and risk factors interact with one another is, at present, impossible.

Similar to the categorisation of risk factors, it is possible to distinguish between static protective factors (e.g. secure childhood attachment or intelligence) and dynamic protective factors (e.g. positive coping strategies or good self-control). However, in 2016, researchers further categorised protective factors into: Promotive factors (variables that have a direct influence on desistence regardless of risk level, e.g. healthy brain development, low neuroticism and having a few good friends rather than numerous acquaintances), risk-based protective factors (variables that predict low probability of offending amongst individuals at risk, e.g. low daring, high school attainment, intelligence), and interactive protective factors (variables that moderate the impact of risk factors; hence, when a risk factor is present, the probability of offending decreases in the presence of a protective factor, for example; high verbal and nonverbal intelligence, high school achievements, high parental interest in education function against poor child-rearing; good parental supervision functions against high dishonesty; and high family income acts as a protective factor against a convicted parent; see Farrington, Ttofi \& Piquero, 2016; Jolliffe, Farrington, Loeber \& Pardini, 2016; Ttofi, Farrington, Piquero \& DeLisi, 2016; Ttofi, Farrington, Piquero, Lösel, DeLisi \& Murray, 2016). Despite much support for this latter classification of protective factors, more research is needed into promotive, risk-based and interactive protective factors in order to truly explain their relationship to offending behaviours and the trajectory to crime. Again, and similar to that mentioned above, we need to deconstruct the term 'protective factors' to further understand the underlying causal mechanisms and how they function to reduce reoffending.

When predicting risk of offending, a lot more is understood about the onset of offending as opposed to the termination of offending.When thinking about those factors that protect an individual, it is important to consider 'desistence' (the process of no longer committing offences amongst those individuals who have previously engaged in a continuous pattern of offending; Maruna, 2001). After all, it is protective factors that contribute most to desistence. Desistence is a 
long-term challenging maintenance process that involves the slow recognition of a need to change, some motivational fluctuations, and some false starts followed by lapses or relapses (McNeill, Farrall, Lightowler, \& Maruna, 2012). To try to understand what promotes desistence from offending, a range of factors and mechanisms have been examined. Some researchers argue that aging causes desistence; thus offenders merely 'grow out of it' (e.g. Glueck \& Glueck, 1940). However, such an explanation does not explain how or why such a change takes place; hence, if we are to truly understand the 'aging effect' then we need to consider the wide range of variables that constitute aging, such as biological changes, social transitions and life experiences, and learn how these variables relate to desistence (Rutter, 1996; Sampson \& Laub, 1992; Sutton, 1994). Other factors found to be linked to desistence include; stable employment, completing schooling, marriage, lack of stress, sobriety, good mental health, optimism and hope, joining the military, sense of achievement, strong self-worth, meaningful relationships, and parenthood (Farrington, Gallagher, Morley, St. Ledger, \& West, 1986; Laub \& Sampson, 2001; LeBel, Burnett, Maruna, \& Bushway, 2008; Leibrich, 1993; Maruna, 2001; Sampson \& Laub, 2005). However, individual differences must be considered: The same social experience can affect individuals in different ways depending on gender, age, previous experiences, race, and personality variables such a conscientiousness and agreeableness (Cowan, 1991; Graham \& Bowling, 1995; Miller \& Lynam, 2001; Rutter, 1996). Additionally, the motivations and internal processes of each individual will have an impact on whether particular factors lead to desistence. For example, stable employment does not cause desistence, but stable employment with commitment to the job is believed to do so (Sampson \& Laub, 1993). Hence, we cannot just list factors that protect the individual and promote desistence from crime. Instead, we must consider how the individual as a whole desists from crime by considering how these descriptive categories associated with desistance relate to individual internal processes.

Evidence from the desistence literature clearly emphasises the importance of identifying people's strengths if the desistence process is to occur. By focusing on why and how some individuals succeed (i.e. the protective factors) and no longer focusing on why and how some individuals fail (i.e. the risk factors), desistence research can help to implement new understandings for offender assessment and treatment (de Vries Robbé, Mann, Maruna \& Thornton, 2015). However, this can only occur if we stop providing lists of factors that protect individuals from reoffending and start providing explanations of how and why such factors protect individuals from reoffending. A greater understanding of how the protective factors can be used to overcome obstacles to desistence will encourage criminal justice practice to start supporting and developing these positive attributes within offenders (Maruna \& LeBel, 2003, 2009). 
To summarise, the reliance on measuring risk factors as correlates of recidivism is misleading and means that the focus of assessment and treatment is on the offender's 'problems' and not on the offender's 'positive attributes and qualities'. It is extremely helpful that scholars are now beginning to examine the latter by defining protective factors and unpicking their meaning (e.g. in the special issue by Ttofi et al., 2016). After all, the incorporation of such factors improves the predictive validity of risk assessments and is more attractive to communities (Pollard, Hawkins \& Arthur, 1999). However, research now needs to continue to examine the notion of 'protective factors': Evidence shows that in their current format, protective factors are not 'mirror images' of risk factors or causes of desistence, but instead are indicators of reduced recidivism or predictors of desistence. If protective factors are to have causal links then future research needs to explore more thorough conceptualisations of protective factors that have more explanatory value. That is, in order for protective factors to hold any meaning, we need to understand how they have an effect on recidivism and desistance. One factor that has previously been discussed as a dynamic risk factor is expertise (Vernham \& Nee, 2015). However, this factor could also be a protective factor and thus will be the focus of the next part of this article.

\section{What is expertise and how might it develop in individuals?}

Expertise refers to the skills and knowledge an individual develops through learning and concerted practice in a particular domain that makes them distinguishable and obviously superior from those new to that domain (i.e. the novice). The kind of expertise discussed in this article refers to a continuum of expertise (Chi \& Bassok, 1989; Hoffman, Shadbolt, Burton \& Klein, 1995) with novices at one end and masters at the other. Most individuals have the ability to develop expertise in some domains (for instance, many of us go from novice to expert in relation to driving a car), but it is rare for individuals to reach the extreme end of proficiency, except through continual, deliberate and challenging practice (Ericsson, 1996). Expertise in a given field can be conceptualised as both structural representations in memory and their behavioural manifestations.

There is a large and long-established body of literature and research devoted to understanding the cognitive processes associated with the development of expertise, involving numerous domains (for example, chess players, pilots, doctors, typists, and firefighters to name but a few; see Vicente \& Wang, 1998 for a review). Others have noted processes and features which unify experts, whatever their domain (Feltovich, Prietula \& Ericsson, 2006; Nee \& Ward, 2015; Palmeri, Wong \& Gauthier, 2004). Key aspects include; the development of dense and interconnected cognitive schemas in long-term memory; automaticity in decision-making and behaviour; selective preconscious attention; and heightened situational awareness of cues relevant to their domain of expertise (these will each be briefly described below, but for a fuller account see Nee \& 
Ward, 2015). These four distinguishing features allow the expert to undertake faster, automatic and cognitively more economical decisions in relation to their less experienced peers, regardless of which area of expertise is under examination.

As a novice begins to practice a skill they are eventually to become expert at (e.g. learning to play the piano), through trial and error they become increasingly attuned to the cues (e.g. visual/auditory; external/internal) in their environment that represent successful choices and decisions, and also those that are less useful and should therefore be ignored. As skill builds, the individual begins to chunk together in memory these patterns of recognition and knowledge about how to respond (in this case to the sheet music), allowing them to play more quickly and efficiently. These memory structures or patterns about how to behave are known as cognitive schemas (Shanteau, 1992) and they become richer and more inter-connected as practice ensues. Decades of experimental and interview research on, for instance, chess players (De Groot, 1946; Gobet \& Simon, 1996), diagnostic expertise in doctors (Norman, Eva, Brooks \& Hamstra, 2006), and computer programmers (Barfield, 1997) has shown that the recall processes used by these experts are faster, more detailed and more strategy orientated compared to control groups.

Another well-established idea is that as an individual becomes well-practiced at a skill, it becomes automatic and beneath explicit consciousness (e.g. being able to drive without thinking about it; being able to play a tune without instructing oneself which notes to play). Robust experimental evidence has indicated that automaticity has four distinct features (the process should be unintentional, outside awareness, uncontrollable and highly resource-efficient) and often requires thousands of repeated learning episodes (Shiffrin \& Shneider, 1977). More recent scholars have noted that consciousness is a continuum and some aspects of a thought-processing episode (e.g. deciding to make a trip somewhere) will be conscious, while other more routine aspects (actually driving the car there) will be mostly below consciousness (Bargh, 1994; Norman et al., 2006).

Other key aspects of expertise include selective preconscious attention and heightened situational awareness of cues in the environment. Bargh and his colleagues have eloquently described the preconscious automatic processes that develop with learning and practice in any domain, allowing the individual to unconsciously scan the environment for triggers associated with reward or threat (Bargh, Gollwitzer, Lee-Chai, Barndollar \& Trotschel, 2001). Evidence from experimental psychology indicates that these processes, which from an evolutionary point of view, are linked to self-preservation, allow an “eternal vigilance” (Bargh, 1994, p. 5), and are "chronically accessible” (Bargh, 1994, p. 4; i.e. they are permanently functioning processes that are very difficult, if not impossible, to 'turn off').

All-in-all, the four features associated with expertise allow for; increasingly accurate, automatic and unconscious recognition of relevant stimuli and instantaneous action (Chase \& 
Simon, 1973; Logan, 1988); faster coding of familiar stimuli (Chi, Feltovich \& Glaser, 1981; Klein, 1993); and the ability to multi-task (Palmeri et al., 2004) as working memory is free to deal with novel challenges.

\section{Functional and dysfunctional expertise}

The account of expertise above describes processing and competencies that clearly enhance the lives of those who have developed it, as these types of expertise allow more effective performance in functional, legitimate ways.

Conceptualising expertise as a continuum (Bedard \& Chi, 1992; Chi, 2006) explains how most motivated novices can develop a level of knowledge and skill through learning and practice that affords a more cognitively economical and speedy execution of behaviour, be it learning a second language, learning to type, or diagnosing a brain tumor. That said, it is well-established that the majority of persistent offenders have grown up in impoverished conditions characterised by genetic, familial and environmental disadvantage (Farrington \& Welsh, 2006). The chaotic and impoverished background of most offenders is unlikely to offer the neurological prerequisites desired to foster cognitive, behavioural and interpersonal competencies. Sufficient nutrition, rest, a stimulating and loving environment; ample opportunity to observe prosocial behaviour; consistent rewards for the incremental development of self-regulation and empathy for others; a childhood free from physical violence and access to toxic substances; are not the typical context of the child more likely to become an offender. These prerequisites of emotion regulation, impulse control and empathy are often sadly lacking (Liu, 2011; Nee \& Ioannou, in press; Obradovic, 2010).

Despite these far from ideal circumstances, work in the nascent field of expertise in offenders is littered with examples of ways in which offenders' decision-making, spatial navigation and execution of tasks is superior to a range of control groups, including students (Nee et al., 2015; Topalli, 2005), householders (Nee \& Taylor, 2000) and other offenders (Logie, Wright \& Decker, 1992), albeit restricted to the domain of committing specific crimes ${ }^{1}$. Notwithstanding the impact that the amount or 'dosage' of disadvantage experienced in childhood can be, alongside the individual differences in response to adversity a child can have, and how these result in the development of maladaptive behaviour (Bonanno \& Diminich, 2013; Bonanno, Galea, Bucciarrelli, \& Vlahov, 2007), it is remarkable that a large proportion of those exposed to chronic adversity go on to lead functional and fulfilling lives (Masten \& Netanaya, 2012; Rutter, 1985, 2006). While one could argue that chronic and persistent offenders are not in this (resilient) group, the age-crime curve (Loeber \& Farrington, 2014) may in fact support this argument, if one views offending behaviour as a possible consequence of developmental delay (as a consequence of the adversity

\footnotetext{
${ }^{1}$ However, this is not unusual as an established characteristic of expertise in general is that it is highly domain-limited (Gobet \& Simon, 1996).
} 
noted above) and the fact that the majority of offenders have grown out of crime by their midtwenties. Unfortunately, experience within the Criminal Justice System (CJS) considerably increases the obstacles these young people face when attempting to adjust to 'normal' life, but as practitioners and academics involved in the reduction of crime we ignore these abilities to develop competencies in the face of considerable adversity at our peril.

\section{The nature of dysfunctional expertise and its potential role as a protective factor}

Nee and Ward (2015) have developed a theoretical model of 'dysfunctional' expertise as a way of explaining what is normally seen as a competency, but in offenders. What is compelling is that both functional and dysfunctional expertise share the same features (Nee \& Ward, 2015). There is evidence that both involve the following stages of cognitive processing:

1. Automatic, unintentional, pre-conscious appraisal of the environment that cannot be turned off;

2. Superior, automatic recognition of the environmental, offence-related cues meaningfully related to the domain of expertise;

3. The activation of complex cognitive schemas, built up through practice, allowing instantaneous, compensatory access to a rich number of exemplars and heuristics which will in turn guide;

4. Speedy responses to environmental cues that have worked in the past in the form of the playing out of behavioural scripts, allowing a relatively automatic commission of the act.

For offenders, most evidence comes from empirical work associated with decision-making in burglars (see Nee, 2015 for a review) but superior knowledge of cues, script-like knowledge and ease/automaticity of behaviour have been cited frequently in interview studies in the emerging literature, for example, implicit planning in child sex offenders and identity thieves (Ward \& Hudson, 2000; Vieraitis, Copes, Powell \& Pike, 2015) and use of automatic scripts in sex offenders (Bourke, Ward \& Rose, 2012; Fortune, Bourke \& Ward, 2015), firesetters (Butler \& Gannon, 2015), and carjackers (Topalli, Jacques \& Wright, 2015).

For example, in research using crime scene data, burglars are seen to use clean, systematic routes to and around the crime scene (indicating superior appraisal of cues and more script-like knowledge, Bernasco \& Luykx, 2003) and this has been replicated in experiments in numerous studies in relation to control groups of householders and students who are slower and more haphazard in their search (Logie et al., 1992; Nee \& Taylor, 2000; Rengert \& Wasilchick, 2000; Wright, Logie \& Decker, 1995). Target selection has been shown to be faster with the use of a 
fewer numbers of cues (Garcia-Retamero \& Dhami, 2009; Homel, Macintyre \& Wortley, 2014; Nee \& Taylor, 2000; Snook, Dhami \& Kavanagh, 2011). The more limited research on behaviour inside the target again exemplifies more economical cognitive processes built on prior learning including a faster, cleaner, more focused and more efficient searching for goods resulting in a greater net gain (Nee \& Meenaghan, 2006; Nee et al., 2015; Wright \& Decker, 1996). Burglars describe being on 'automatic pilot' (Nee \& Meenaghan, 2006) suggesting the triggering of automatic scripts based on dense schemas. The work completed on child molesters indicates a somewhat different array of expertise including covert and symbolic modelling, rehearsal, observational learning, and through an offender's own experience of early sexual or physical abuse (Ward, 1999). Bourke et al.’s (2012) in-depth interviewing of a range of child sexual offenders suggested considerably more superior, automatic recognition of cues relating to vulnerable targets and contexts in the more experienced offenders. Rich schemas in memory were also described involving interconnected information about previous, current, and future victims. Individuals appeared to access these stores of knowledge and associated offending scripts when selecting strategies for current and future offenses. In sum, the study showed that expert child sexual offenders exhibited an enhanced ability to; detect emotional vulnerability of potential victims; avoid detection for offenses committed; effectively regulate and manage excessive emotional arousal; and have better problem-solving skills than less experienced offenders.

Indeed, the unusual nature of expertise in offenders is that it can be envisaged as both a risk and protective factor. Moreover, a benefit is that unlike many of the risk and protective factors listed in the literature as associated with offending, there is a wealth of research and theory that aims to explain the nature of expertise (Chase \& Simon, 1973; Chi et al., 1981; Klein, 1993), how it develops (Ericsson, 1996) and what its limitations are (Chi, 2006; Dror, 2011; Klein, 2009). Ericsson (2006) notes in the introductory chapter of the Cambridge Handbook of Expertise and Expert Performance that an expert is someone who is "widely recognised as a reliable source of knowledge, technique or skill whose judgment is accorded authority and status by the public or his peers” (p. 3). We do not ascribe these positive attributes to persistent offenders who are likely to have done considerable damage to their victims and themselves as a result of their periods of offending. Nevertheless, the competencies associated with their expertise are worth a closer look in order to unpick aspects which may be useful in helping them give up their dysfunctional behaviour.

We know in a typically developing and well-adjusted child that at around three years of age the anterior cingulate cortex in the brain begins to play a crucial role in the development of impulse control and executive functioning in the ventromedial prefrontal cortex (Rueda, Posner \& Rothbart, 2005) and that this may be one of the key deficiencies in the development of the disadvantaged child (who may not be receiving appropriate nutrition, rest or security and may be subject to 
physical or emotional abuse or neglect). This renders them less able to control inbuilt impulses (i.e. to think before acting), especially when immediate reward is involved, and the resulting lack of self-regulation is known to be strongly correlated with a number of negative outcomes in adolescence and adulthood including psychopathology and antisocial behaviour (Dalley \& Roiser, 2012). Despite this problematic start, it must be acknowledged that many of the cognitive prerequisites for developing the competencies associated with expertise; a good working memory, ability for mental imagery, pattern recognition and sustained concentration; and ability for counterfactual thinking, planning and problem solving, appear to have developed at least to some extent in the offender. While the offender should not be congratulated for these abilities, in a strengths-based rehabilitation approach, it should be possible to recruit these competencies and work with them towards prosocial behaviours. For example, the experienced child sex offender will have an enhanced ability to assess vulnerability in potential victims and will have developed considerable interpersonal skills in grooming the child. Bearing in mind his/her primary goal is likely to be the legitimate one of intimacy, these skills can be turned around into prosocial strategies for developing relationships with adults. Similarly, the heightened situational awareness of cues signifying vulnerable buildings characteristic of the burglar, bearing in mind his/her primary goal of needing to feed and clothe him/herself, could be successfully channelled into a legitimate role in environmental crime prevention. His/her ability to search buildings notably more effectively than a variety of novice groups could be used in such activities as bomb disposal. In this way, the expertise developed can be used to underpin a growing sense of agency in the individual. If conceptualised like this, expertise can be seen as a naturally occurring strength/competency/protective factor which develops in spite of adversity and can be recruited to support desistance from crime. As a result of these features of expertise, and the ability of the disadvantaged young person to acquire them, we cannot afford to ignore it in the field of correctional psychology and criminology.

\section{Implications for rehabilitation and desistance}

The current review has identified that it is important to understand more clearly the role of protective factors and how they should be conceptualised. The theoretical and practical implications for understanding protective factors are numerous and many have been mentioned above (e.g. implications for treatment and rehabilitation). Of particular importance to mention here is that protective factors and the positive approach of incorporating the offenders' strengths into risk assessment corresponds with the Good Lives Model (GLM) of rehabilitation (Ward \& Gannon, 2006; Ward \& Stewart, 2003). The GLM is a strengths-based approach that focuses on human agency by aiming to build capabilities within an offender in line with his/her existing values and 
interests. Additionally, it attempts to capitalise on an offender's existing abilities and what s/he is already 'good' at (Ward \& Fortune, 2013). In this sense, expertise has a valuable role to play given that many offenders will have already built up the competencies described above. The GLM recognises that offenders need to be sufficiently motivated to desist from crime (Ward \& Stewart, 2003) and therefore the GLM is concerned with helping the individual to formulate goals and construct plans based around eleven primary goods (e.g. life, knowledge, excellence in work, inner peace; Purvis, 2010; Ward \& Brown 2004; Ward \& Marshall, 2004). The GLM has been employed successfully to aid with the desistence of crime for various types of offenders, including sexual offenders (e.g. Ward \& Fortune, 2013) and, more recently, residential burglars (e.g. Taylor, 2016). Taylor (2016) provides qualitative evidence of competencies in burglars and how they dysfunctionally map on to the primary human goods of life, excellence in work and excellence in agency, and how these could be harnessed in a strengths-based intervention. She demonstrates that it is lack of fulfilment of a particular primary good and/or the pursuit of a primary good that contributes towards the individual's criminal activity; hence, if practitioners develop 'good lives plans' during case management and intervention that focus on the individual's personal strengths and competencies, then this will help the offender to achieve the primary goods.

The protective factors approach and in particular the notion of expertise as a protective factor can clearly be incorporated within the GLM to: (i) increase the sense of agency and consequent motivation to desist that this affords; (ii) support the offender in learning new (prosocial) skills; and (iii) assist the offender in reapplying the features of expertise from dysfunctional to functional within one or more areas of the primary goods. These new competencies will positively benefit the offender by reducing the need for the offender to achieve a 'good life' through criminal activity. That is, s/he will be able to pursue the eleven primary goods through more socially-acceptable means. For example, a residential burglar who has previously achieved the primary good of 'life' through obtaining money via stealing can instead achieve the primary good of 'life' through obtaining money via employment and a more secure standard of living. Furthermore, a residential burglar who has previously achieved the primary good of 'knowledge' through learning how to overcome complicated security measures, such as sophisticated or multiple locks, can instead achieve the primary good of 'knowledge' through developing new skills via studying or training. The overall aim of the GLM and the incorporation of expertise as a protective factor is to render the life of the offender more meaningful and productive. The offender will learn and identify the role that their criminal behaviour has in fulfilling the eleven primary goods, so can develop the skills to achieve these goods in a more pro-social manner; thus, desisting from offending. This ability to fulfil a 'good life' and show capability in something other than offending 
will promote positive well-being in the offender (Hefferon \& Boniwell, 2011; Seligman \& Csikszentmihalyi, 2000) and reduce the risk of re-offending (Purvis, Ward \& Willis, 2011).

Knowledge of the cognitive features of expertise will present new hurdles in rehabilitation. The unconscious awareness of and selective attention for dysfunctional cues, and the automatic behavioural scripts these trigger will present a particular challenge for those who wish to give up criminal behaviour (or indeed any damaging behaviour) and for those wishing to assist them in this pursuit. Nevertheless, progress has been made in other fields in which damaging automatic processes and behaviours are a central feature. Evidence is accruing that dysfunctional automatic responses to meaningful triggers can be replaced by functional ones in the fields of; social discrimination; depression and anxiety; and eating behaviour (see Vernham \& Nee, 2015 for more detail). These challenges, however, may be more than outweighed by the increased commitment and motivation afforded by taking the strengths-based approach.

Importantly, the ability to develop these competencies despite adversity provides hope that there are nascent abilities in the most ill-fated young people and that these can be nurtured even before they start a life of crime. In the de Vries Robbé et al. (2015) model, these innate potentials for competency would be conceptualised as protective factors with a 'motivator' effect (i.e. potentials that support the development of other positive features). These ideas are also supported by recent theory and research on neural plasticity in brain development. Once thought to be at its peak in early childhood, scholars now propose that susceptibility to the impact of environmental adversity (or opposite) varies from individual to individual and may change throughout childhood and adolescence (Belsky et al., 2009; Ellis, Boyce, Belsky, Bakermans-Kranenburg, \& van Ijzendoorn, 2011).

Thus, the influence of protective factors on prevention, rehabilitation and desistence has direct policy implications for the CJS and in particular crime prevention. Not only should risk factors continue to be a target of interventions, but so should protective factors. Through the inclusion of desistence and strengths, additional guidance will be in place during the assessment and intervention of those who offend, and by understanding expertise we can recognise those processes and behaviours that contribute to the development of offending behaviours. Therefore we can focus on adjusting these processes and behaviours into more adaptive and positive (i.e. sociallyacceptable) behaviours. By focusing on positive human change and development, we can avoid the negative labeling and unintended negative consequences that such labelling can produce (McNeil et al., 2012). That is, by incorporating both risk and protective factors in correctional practice, the predictive validity of assessments will improve and the planning of offender treatment programs will be more constructive meeting the needs of each individual offender. Hence, it is expected that 
in the long run reoffending rates will decrease when a positive approach is applied to offender treatment and rehabilitation.

\section{Further research}

Overall, more research is needed to disentangle the contribution of protective factors from those of risk factors, as well as to identify the role of specific protective factors in offending and the management strategies that are needed to enhance such factors. Further research should also explore the time frame in which protective factors play a role in desistence and whether this time frame is dependent on other factors, such as risk factors, offence characteristics or demographic factors. The more that is known about protective factors, the greater utility they will have in the assessment, management and treatment of individual offenders. Continuing research on expertise and its role in the rewards associated with crime and the sense of agency it affords will also help illuminate its role as both a risk and a protective factor in the development of criminal activity.

\section{Conclusion}

A better understanding of how and why people avoid, embark upon and desist from offending offers us the opportunity to develop better criminal justice practices, processes, policies, and helps us to provide more support for the offender during rehabilitation and reintegration into the community.

What is apparent from this article is that, while there is clear evidence that offenders demonstrate competencies, we know very little about the nature of the skills, strengths and potentials young people at risk of offending might have, how these are related to agency and reward, and how they could be recruited in the prevention of and desistence from offending. It is hoped that this article will spark further research into protective factors, including expertise, to result in a broader evidence base for the prevention of offending and the assessment and treatment of those who are already offending. 


\section{References}

Afifi, T.O., \& MacMillan, H.L. (2011). Resilience following child maltreatment: A review of protective factors. Canadian Journal of Psychiatry, 56, 266-272. DOI: 10.1177/070674371105600505.

Andrews, D.A., \& Bonta, J. (2003). The psychology of criminal conduct ( $3^{\text {rd }}$ Eds.). Cincinnati, OH: Anderson.

Andrew, D.A., Bonta, J. \& Wormith, S. (2006). The recent past and near future of risk/need assessment. Crime and Delinquency, 52, 7-27. DOI: 10.1177/0011128705281756.

Attrill, G., \& Liell, G. (2007). Offenders views on risk assessment. In N. Padfield (Eds.), Who to release? Parole, fairness and criminal justice (pp. 191-201). Cullompton, UK: Willan.

Barfield, W. (1997). Skilled performance on software as a function of domain expertise and program organization. Perceptual and Motor Skills, 85, 1471-1480. DOI: 10.2466/pms.1997.85.3f.1471.

Bargh, J. (1994). The four horsemen of automaticity: Awareness, intention, efficiency, and control in social cognition. In R. Wyer \& T. Srull (Eds.), Handbook of Social Cognition (pp. 1-40). Hillsdale, New Jersey: Lawrence Erlbaum Associates, Inc.

Bargh, J.A., Gollwitzer, P.M., Lee-Chai, A., Barndollar, K., \& Trotschel, R. (2001). The automated will: Non-conscious activation and pursuit of behavioral goals. Journal of Personality and Social Psychology, 81, 1014-1027. DOI: 10.1037/0022-3514.81.6.1014.

Bedard, J., \& Chi, M. (1992). Expertise. Current Directions in Psychological Science, 1, 135-139. DOI: 10.1111/1467-8721.ep10769799.

Beech, A.R., Fisher, D.D., \& Thornton, D. (2003). Risk assessment of sex offenders. Professional Psychology: Research and Practice, 34, 339-352. DOI: 10.1037/0735-7028.34.4.339.

Belsky, J., Jonassaint, C., Pluess, M., Stanton, M., Brummett, B., \& Williams, R. (2009). Vulnerability genes or plasticity genes? Molecular Psychiatry, 14, 746-754. DOI: $10.1038 / \mathrm{mp} .2009 .44$.

Bernasco, W., \& Luykx, F. (2003). Effects of attractiveness, opportunity and accessibility to burglars on residential burglary rates of urban neighbourhoods. Criminology, 41, 3, 981-1002. DOI: 10.1111/j.1745-9125.2003.tb01011.x. 
Bonano, G.A. \& Diminich, E. D. (2013). Annual Research Review: Positive adjustment to adversity--trajectories of minimal-impact resilience and emergent resilience. Journal of Child Psychology and Psychiatry, 54, 378-401. DOI: 10.1111/jcpp.12021.

Bonanno, G.A., Galea, S., Bucciarelli, A., \& Vlahov, D. (2007). What predicts psychological resilience after disaster? The role of demographics, resources, and life stress. Journal of Consulting and Clinical Psychology, 75, 671-682. DOI: 10.1037/0022-006X.75.5.671.

Bonta, J. (1996). Risk-needs assessment and treatment. In A.T. Harland (Eds.), Choosing correctional options that work: Defining the demand and evaluating the supply (pp. 18-32). Thousand Oaks, CA: Sage.

Bourke, P., Ward, T., \& Rose, C. (2012). Expertise and sexual offending: A preliminary empirical model. Journal of Interpersonal Violence, 27, 2391- 2414. DOI: 10.1177/0886260511433513.

Butler, H., \& Gannon, T. (2015). The scripts and expertise of firesetters: A preliminary conceptualization. Aggression and Violent Behavior, 20, 72-81. DOI: 10.1016/j.avb.2014.12.011.

Chase, W.G., \& Simon, H.A. (1973). Perception in Chess. Cognitive Psychology, 4, 55-81. DOI : 10.1016/0010-0285(73)90004-2.

Chi, M.T.H. (2006). Two approaches to the study of experts' characteristics. In K. Ericsson, N. Charness, P. Feltovich \& R. Hoffman (Eds.), The Cambridge handbook of expertise and expert performance (pp. 21-30). Cambridge: Cambridge University Press.

Chi, M.T.H., \& Bassok, M. (1989). Learning from examples via self-explanations. In L.B. Resnick (Eds.), Knowing, learning, and instruction: Essays in honor of Robert Glaser (pp. 251-282). Hillsdale, NJ: Erlbaum.

Chi, M.T.H., Feltovich, P., \& Glaser, R. (1981). Categorisation and representation of physics problems by experts and novices. Cognitive Science, 5, 121-152.

DOI: 10.1207/s15516709cog0502_2.

Costa, F.M., Jessor, R., \& Turbin, M.S. (1999). Transition into adolescent problem drinking: The role of psychosocial risk and protective factors. Journal of Studies on Alcohol, 60, 480-490. DOI: $10.15288 /$ jsa.1999.60.480.

Cowan, P.A. (1991). Individual and family life transitions: A proposal for a new definition. In P.A. Cowan \& E.M. Hetherington (Eds.), Family Transitions (pp. 3-30). Hillsdale, NJ: Lawrence Erlbaum Associates, Inc.

Dalley, J. \& Roiser, J. (2012). Dopamine, serotonin and impulsivity. Neuroscience, 215, 42-58. DOI: 10.1016/j.neuroscience.2012.03.065. 
de Groot, A.D. (1946). Het denken van de schaker. [The thought of the chess player]. Amsterdam: North-Holland. Updated translation published as Thought and choice in chess. Mouton, The Hague.

de Vogel, V., de Vries Robbé, M., de Ruiter, C., \& Bouman, Y.H.A. (2011). Assessing protective factors in forensic psychiatric practice: Introducing the SAPROF. International Journal of Forensic Mental Health, 10, 171-177. DOI: 10.1080/14999013.2011.600230.

de Vries Robbé, M. (2014). Protective factors: Validation of the structured assessment of protective factors for violence risk in forensic psychiatry (doctoral thesis). Retrieved from: http://www.saprof.com/_files/Phd\%20Thesis\%20Protective\%20Factors.\%20Michiel\%20de\% 20Vries\%20Robbe.pdf.

de Vries Robbé, M., de Vogel, V., \& de Spa, E. (2011). Protective factors for violence risk in forensic psychiatric patients: A retrospective validation study of the SAPROF. International Journal of Forensic Mental Health, 10, 178-186. DOI: 10.1080/14999013.2011.600232. de Vries Robbé, M., de Vogel, V., \& Douglas, K.S. (2013). Risk factors and protective factors: A two-sided dynamic approach to violence risk assessment. Journal of Forensic Psychiatry \& Psychology, 24, 440-457. DOI: 10.1080/14789949.2013.818162.

de Vries Robbé, M., Mann, R.E., Maruna, S., \& Thornton, D. (2015). An exploration of protective factors supporting desistance from sexual offending. Sexual abuse: A Journal of Research and Treatment, 27, 16-33. DOI: 10.1177/1079063214547582.

Dror, I.E. (2011). The paradox of human expertise: Why experts can get it wrong. In N. Kapur (Eds.), The Paradoxical Brain (pp. 177-188). Cambridge, UK: Cambridge University Press. Ellis, B.J., Boyce, W.T., Belsky, J., Bakermans-Kranenburg, M.J., \& van Ijzendoorn, M.H. (2011). Differential susceptibility to the environment: An evolutionary-neurodevelopmental theory. Development and Psychopathology, 23, 7-28. DOI: 10.1017/S0954579410000611.

Ericsson, K.A. (1996). The acquisition of expert performance: An introduction to some of the issues. In K.A. Ericsson (Eds.). The road to excellence: The acquisition of expert performance in the arts and sciences, sports, and games (pp. 1-50). Mahwah, NJ: Erlbaum.

Ericsson, K.A. (2006). An introduction to the Cambridge handbook of expertise and expert performance: Its development, organisation and content. In K. Ericsson, N. Charness, P. Feltovich, \& R. Hoffman (Eds.), The Cambridge handbook of expertise and expert performance (pp. 3-20). Cambridge: Cambridge University Press.

Farrington, D.P., Gallagher, B., Morley, L., St. Ledger, R.J., \& West, D.J. (1986). Unemployment, school leaving, and crime. British Journal of Criminology, 26, 335-356. 
Farrington, D.P., Ttofi, M.M., \& Piquero, A.R. (2016). Risk, promotive, and protective factors in youth offending: Results from the Cambridge study in delinquent development. Journal of Criminal Justice, 45, 63-70. DOI: 10.1016/j.jcrimjus.2016.02.014.

Farrington, D., \& Welsh, B. (2006). Saving Children from a Life of Crime: Early Risk Factors and Effective Interventions. Oxford: Oxford University Press.

Feltovich, P.J., Prietula, M.J, \& Ericsson, K.A. (2006). Studies of expertise from psychological perspectives. In K. Ericsson, N. Charness, P. Feltovich \& R. Hoffman (Eds.), The Cambridge handbook of expertise and expert performance (pp. 41-68). Cambridge: Cambridge University Press.

Fortune, C., Bourke, P., \& Ward, T. (2015). Expertise and child sex offenders. Aggression and Violent Behavior, 20, 33-41. DOI: 10.1016/j.avb.2014.12.005.

Garcia-Retamero, R., \& Dhami, M.K. (2009). Take-the-best in expert-novice decision strategies for residential burglary. Psychonomic Bulletin \& Review, 16, 163-169. DOI: 10.3758/PBR.16.1.163.

Glueck, S., \& Glueck, E. (1940). Juvenile delinquents grown up. New York: Commonwealth Fund. Gobet, F., \& Simon, H.A. (1996). Recall of rapidly presented random chess positions is a function of skill. Psychonomic Bulletin \& Review, 3, 159-163. DOI: 10.3758/BF03212414.

Graham, J., \& Bowling, B. (1995). Young people and crime. London: Home Office.

Hefferon, K., \& Boniwell, I. (2011). Positive psychology: Theory, research and applications. McGraw Hill: Open University Press.

Hoffman, R., Shadbolt, N., Burton, A., \& Klein, G. (1995). Eliciting knowledge from experts: A methodological analysis. Organizational Behavior and Human Decision Processes, 62, 129158. DOI: 10.1006/obhd.1995.1039.

Homel, R., Macintyre, S., \& Wortley, R. (2014). How burglars decide on targets: A computer-based scenario approach. In B. LeClerc \& R. Wortley (Eds.), Cognition and crime: Offender decision making and script analyses (pp. 26-47). Oxford: Routledge.

Jolliffe, D., Farrington, D.P., Loeber, R., \& Pardini, D. (2016). Protective factors for violence: Results from the Pittsburgh Youth Study. Journal of Criminal Justice, 45, 32-40. DOI: 10.1016/j.jcrimjus.2016.02.007.

Klein, G.A. (1993). A recognition-primed decision (RPD) model of rapid decision-making. In G.A. Klein, J. Orasanu, R. Calderwood \& C. Zsambok (Eds.), Decision-making in action: Models and methods (pp. 138-147). Norwood, New Jersey: Ablex Publishing Corporation.

Klein, G.A. (2009). Streetlights and shadows: Searching for the keys to adaptive decision-making. Cambridge, MA: MIT Press. 
Laub, J.H., \& Sampson, R.J. (2001). Understanding desistance from crime. In M. Tonry (Eds.), Crime and justice (pp. 1-69). Chicago: University of Chicago Press.

LeBel, T.P., Burnett, R., Maruna, S., \& Bushway, S. (2008). The “chicken and egg” of subjective and social factors in desistance from crime. European Journal of Criminology, 5, 131-159. DOI: $10.1177 / 1477370807087640$.

Leibrich, J. (1993). Straight to the point: Angles on giving up crime. University of Otago Press: Otago.

Liu, J. (2011). Early health risk factors for violence: Conceptualization, review of the evidence, and implications. Aggression and Violent Behavior. 16, 1, 63-73. DOI: 10.1016/j.avb.2010.12.003

Lodewijks, H.P.B., de Ruiter, C., \& Doreleijers, T.A.H. (2010). The impact of protective factors in desistence from violent reoffending. Journal of Interpersonal Violence, 25, 568-587. DOI: $10.1177 / 0886260509334403$.

Loeber, R., \& Farrington, D.P. (2014). The age-crime curve. In G. Bruinsma \& D. Weisburd (Eds.), Encyclopaedia of Criminology and Criminal Justice (pp. 12-18). New York: Springer.

Logan, G.D. (1988). Toward an instance theory of automatization, Psychological Review, 95, 492527. DOI: 10.1037/0033-295X.95.4.492.

Logie, R.H., Wright, R.T. \& Decker, S. (1992). Recognition memory performance and residential burglary. Applied Cognitive Psychology, 6, 109-123. DOI: 10.1002/acp.2350060203.

Maruna, S. (2001). Making good: How ex-convicts reform and rebuild their lives. Washington, DC: APA Books.

Maruna, S., \& LeBel, T. (2003). Welcome home? Examining the "re-entry court" concept from a strengths-based perspective. Western Criminology Review, 4, 91-107.

Maruna, S., \& LeBel, T. (2009). Strengths-based approaches to re-entry: Extra mileage toward reintegration and destigmatization. Japanese Journal of Sociological Criminology, 34, 58-80.

Masten, A.S. (2001). Ordinary magic: Resilience processes in development. American Psychologist, 56, 227-238. DOI: 10.1037//0003-066X.56.3.227.

Masten, A.S., \& Netanaya, A. (2012). Child development in the context of disaster, war, and terrorism: Pathways of risk and resilience. Annual Review of Psychology, 63, 227-57. DOI: 10.1146/annurev-psych-120710-100356.

McNeill, F., Farrall, S., Lightowler, C., \& Maruna, S. (2012). How and why people stop offending: discovering desistance. Institute for Research and Innovation in Social Services. Retrieved from: http://eprints.gla.ac.uk/79860/1/79860.pdf.

Miller, J.D. \& Lynam, D. (2001). Structural models of personality and their relation to antisocial behaviour: A meta-analytic review. Criminology, 39, 765-798. DOI: 10.1111/j.17459125.2001.tb00940.x. 
Mrazek, P. J., \& Mrazek, D. A. (1987). Resilience in child maltreatment victims: A conceptual exploration. Child Abuse \& Neglect, 11, 357-366. DOI: 10.1016/0145-2134(87)90009-3.

Nee, C. (2015). Understanding expertise in burglars: From pre-conscious scanning to action and beyond. Special issue on expertise and offending behavior. Aggression and Violent Behavior. 20, 53-61. DOI: 10.1016/j.avb.2014.12.006.

Nee, C. \& Ioannou, S. (in press). What have neuroscientific approaches to research taught us about acquisitive offenders? In A.R. Beech, A.J. Carter, R.E. Mann \& P. Rotshtein (Eds.), The Wiley-Blackwell Handbook of Forensic Neuroscience. Chichester: John Wiley and Sons.

Nee, C., \& Meenaghan, A. (2006). Expert decision-making in burglars. British Journal of Criminology, 46, 935-949. DOI: 10.1093/bjc/azl013.

Nee, C. \& Taylor, M. (2000). Examining burglars’ target selection: Interview, experiment, or ethnomethodology? Psychology, Crime \& Law, 6, 45-60. DOI: 10.1080/10683160008410831.

Nee, C., \& Ward, T. (2015). Review of expertise and its general implications for correctional psychology and criminology. Aggression and Violent Behavior, 20, 1-9. DOI: 10.1016/j.avb.2014.12.002.

Nee, C., White, M., Woolford, K., Pascu, T., Barker, L. \& Wainwright, L. (2015). New methods for examining expertise in burglars in natural and simulated environments: Preliminary findings. Psychology, Crime \& Law, 21, 507-513. DOI: 10.1080/1068316X.2014.989849.

Norman, G., Eva, K., Brooks, L., \& Hamstra, S. (2006). Expertise in medicine and surgery. In K. Ericsson, N. Charness, P. Feltovich \& R. Hoffman (Eds.), The Cambridge handbook of expertise and expert performance (pp. 339-353). Cambridge: Cambridge University Press.

Obradovic, J. (2010). Effortful control and adaptive functioning of homeless children: Variablefocused and person-focused analyses. Journal of Applied Developmental Psychology, 31, 109117. DOI: 10.1016/j.appdev.2009.09.004.

Palmeri, T.J., Wong, A.C. \& Gauthier, I. (2004). Computational approaches to the development of expertise. Trends in Cognitive Science, 8, 378-386. DOI: 10.1016/j.tics.2004.06.001.

Pollard, J.A., Hawkins, J.D., \& Arthur, M.W. (1999). Risk and protection: Are both necessary to understand diverse behavioural outcomes in adolescence? Social Work Research, 23, 145158. DOI: 10.1093/swr/23.3.145.

Purvis, M. (2010). Seeking a good life: Human goods and sexual offending. Germany: Lambert Academic Press.

Purvis, M., Ward, T., \& Willis, G.M. (2011). The Good Lives Model in practice: Offence pathways and case management. European Journal of Probation, 3, 4-28.

DOI: $10.1177 / 206622031100300202$. 
Rengert, G.F., \& Wasilchick, J. (2000). Suburban burglary: A tale of two suburbs. Chicago: Thomas.

Rogers, R. (2000). The uncritical acceptance of risk assessment in forensic practice. Law and human behavior, 24, 595-605. DOI: 10.1023/A:1005575113507.

Rueda, M., Posner, M. \& Rothbart, M. (2005). The development of executive attention: contributions to the emergence of self-regulation. Developmental Neuropsychology, 28, 573594. DOI: 10.1207/s15326942dn2802_2.

Rutter, M. (1985). Resilience in the face of adversity: Protective factors and resistance to psychiatric disorder. British Journal of Psychiatry, 147, 598-611.

DOI: 10.1192/bjp.147.6.598.

Rutter, M. (1996). Transitions and turning points in developmental psychopathology: As applied to the age span between childhood and mid-adulthood. Journal of Behavioural Development, 19, 603-626. DOI: 10.1177/016502549601900309.

Rutter, M. (2006). Implications of resilience concepts for scientific understanding. Annals of the New York Academy of Sciences, 1094, 1-12. DOI: 10.1196/annals.1376.002.

Salekin, R.T., \& Lochman, J.E. (2008). Child and adolescent psychopathy - The search for protective factors. Criminal Justice and Behavior, 35, 159-172.

DOI: 10.1177/0093854807311330.

Sampson, R.J., \& Laub, J.H. (1992). Crime and deviance in the life course. Annual Review of Sociology, 18, 63-84. DOI: 10.1146/annurev.so.18.080192.000431.

Sampson, R.J., \& Laub, J.H. (1993). Crime in the making: Pathways and turning points through Life. Cambridge, Mass: Harvard University Press.

Sampson, R.J., \& Laub, J.H. (2005). A life-course view of the development of crime. Annals of the American Academy of Political and Social Science, 602, 12-45.

DOI: $10.1177 / 0002716205280075$.

Seligman, M.E.P., \& Csikszentmihalyi, M. (2000). Positive psychology: An introduction. American Psychologist, 55, 5-14. DOI: 10.1037/0003-066X.55.1.5.

Shanteau, J. (1992). How much information does an expert use? Is it relevant? Acta Psychologica, 81, 75-86. DOI: 10.1016/0001-6918(92)90012-3.

Shiffrin, R.M., \& Schneider, W. (1977). Controlled and automatic human information processing: II. Perceptual learning, automatic attending, and a general theory. Psychological Review, 84, 127-190. DOI: 10.1037/0033-295X.84.2.127.

Snook, B., Dhami, M.K., \& Kavanagh, J. (2011). Simply criminal: Predicting burglars' occupancy decisions with a simple heuristic. Law and Human Behavior, 35, 316-326. DOI: 10.1007/s10979-010-9238-0. 
Sutton, J.R. (1994). Children in the therapeutic state: Lessons for the sociology of deviance and social control. In G.S. Bridges \& M.A. Myers (Eds.), Inequality, crime and social control (pp. 227-248). Boulder, CO: Westview Press.

Taylor, E. (2016). 'I should have been a security consultant': The Good Lives Model and residential burglars. European Journal of Criminology, First published online, 1-17. DOI: $10.1177 / 1477370816661743$.

Thornton, D. (2013). Implications of our developing understanding of risk and protective factors in the treatment of adult male sexual offenders. International Journal of Behavioural Consultation and Therapy, 8, 62-65. DOI: 10.1037/h0100985.

Tolan, P. (2000). Youth violence prevention. Chicago: University of Illinois, Institute of Juvenile Research.

Topalli, V. (2005). Criminal expertise and offender decision-making: An experimental analysis of how offenders and non-offenders differentially perceive social stimuli. British Journal of Criminology, 45, 269-295. DOI: 10.1093/bjc/azh086.

Topalli, V., Jacques, S., \& Wright, R. (2015). “It takes skills to take a car”: Perceptual and procedural expertise in carjacking. Aggression and Violent Behavior, 20, 19-25. DOI: 10.1016/j.avb.2014.12.001.

Ttofi, M.M., Farrington, D.P., Piquero, A.R., \& DeLisi, M. (2016). Protective factors against offending and violence: Results from prospective longitudinal studies. Journal of Criminal Justice, 45, 1-3. DOI: 10.1016/j.jcrimjus.2016.02.001.

Ttofi, M.M., Farrington, D.P., Piquero, A.R., Lösel, F., DeLisi, M., \& Murray, J. (2016). Intelligence as a protective factor against offending: A meta-analytic review of prospective longitudinal studies. Journal of Criminal Justice, 45, 4-18. DOI:

10.1016/j.jcrimjus.2016.02.003.

Vernham, Z., \& Nee, C. (2015). Dysfunctional expertise and its relationship with dynamic risk factors in offenders. Psychology, Crime \& Law, 22, 47-67. DOI: 10.1080/1068316X.2015.1109090.

Vicente, K., \& Wang, J. (1998). An ecological theory of expertise effects in memory recall. Psychological Review, 105, 33-57. DOI: 10.1037/0033-295X.105.1.33.

Vieraitis, L., Copes, H., Powell, Z. \& Pike, A. (2015). A little information goes a long way: Expertise and identity theft. Aggression and Violent Behavior, 20, 10-18. DOI: 10.1016/j.avb.2014.12.008.

Ward, T. (1999). Competency and deficit models in the understanding and treatment of sexual offenders. Journal of Sex Research, 36, 298-305. DOI: 10.1080/00224499909552000. 
Ward, T., \& Brown, M. (2004). The Good Lives Model and conceptual issues in offender rehabilitation. Psychology, Crime \& Law, 10, 243-257. DOI:

10.1080/10683160410001662744.

Ward, T., \& Fortune, C.A. (2013). The Good Lives Model: Aligning risk reduction with promoting offenders’ personal goals. European Journal of Probation, 5, 29-46. Retrieved from: http://www.ejprob.ro/index.pl/the_good_lives_model_aligning_risk_reduction_with_promoti ng_offenders_personal_goals.

Ward, T., \& Gannon, T.A. (2006). Rehabilitation, etiology, and self-regulation: The comprehensive good lives model of treatment for sexual offenders. Aggression and Violent Behavior, 11, 7794. DOI:10.1016/j.avb.2005.06.001.

Ward, T., \& Hudson, S.M. (2000). Sexual offenders’ implicit planning: A conceptual model. Sexual Abuse: A Journal of Research and Treatment, 12, 189-202. DOI: 10.1023/A:1009534109157.

Ward, T., \& Marshall, W.L. (2004). Good lives, etiology and the rehabilitation of sex offenders: A bridging theory. Journal of Sexual Aggression, 10, 153-169. DOI: 10.1080/13552600412331290102.

Ward, T., \& Maruna, S. (2007). Rehabilitation. London, UK: Routledge

Ward, T., \& Stewart, C.A. (2003). The treatment of sex offenders: Risk management and good lives. Professional Psychology: Research and Practice, 34, 353-360. DOI: 10.1037/07357028.34.4.353.

Werner, E.E., \& Smith, R.S. (1982). Vulnerable but invincible: A longitudinal study of resilient children and youth. New York: McGraw-Hill Book Company.

White, J.L., Moffitt, T.E., \& Silva, P.A. (1989). A prospective replication of the protective effects of IQ in subjects at high risk for juvenile delinquency. Journal of Consulting and Clinical Psychology, 57, 719-724. Retrieved from: http://facweb.northseattle.edu/lchaffee/PSY100/Journal\%20Articles/White\%20et\%20al\%201 989.pdf.

Willis, G.M., \& Ward, T. (2013). The good lives model. In L.A. Craig, T.A. Gannon, \& L. Dixon (Eds.), What works in offender rehabilitation: An evidence-based approach to assessment and treatment (pp. 305-317). Chichester, United Kingdom: Wiley-Blackwell.

Wilson, R. J., \& Yates, P. M. (2009). Effective interventions and the Good Lives Model: Maximizing treatment gains for sexual offenders. Aggression and Violent Behavior, 14, 157161. DOI: 10.1016/j.avb.2009.01.007.

Wright, R. T., \& Decker, S. H. (1996). Burglars on the job: Streetlife and residential break-ins. Boston: Northeastern University Press. 
Wright, R.T., Logie, R.H. \& Decker, S.H. (1995). Criminal expertise and offender decision making: an experimental study of the target selection process in residential burglary. Journal of Research in Crime and Delinquency, 32, 39-53. DOI: 10.1177/0022427895032001002. 